\title{
Poverty and Digital Divide: A Study in Urban Poor Neighborhoods
}

\author{
Tri Mulyaningsih ${ }^{1}$, Rutiana Wahyunengseh ${ }^{2}$, Sri Hastjarjo ${ }^{3}$ \\ ${ }^{1}$ Department of Economics, FEB Universitas Sebelas Maret (email: trimulyaningsih@staff.uns.ac.id) \\ ${ }^{2}$ Department of Public Administration, FISIP, Universitas Sebelas Maret (email: rutiana.uns@gmail.com) \\ ${ }^{3}$ Department of Communication, FISIP, Universitas Sebelas Maret (email: sri.hastjarjo@staff.uns.ac.id)
}

\begin{abstract}
Literature suggests that the penetration of digital technology may create a digital divide, particularly for groups that lack resources and the capacity to access technology. This study is keen to examine the poverty and digital divide, particularly in urban poor areas. There are two research objectives. Firstly, to examine the digital diffusion and digital literacy within poor urban neighborhoods in the City of Magelang, Central Java, Indonesia. Secondly, to understand the variation of digital diffusion and digital literacy across areas (with different levels of poverty), age groups, genders and occupations. The data is collected from surveys focused on measuring the access to information, digital diffusion and the use of technology among the poor. This study found that there is a digital divide problem among people in urban areas, especially among people with low incomes. Moreover, the diffusion is dominated by certain groups such as younger people and females. Furthermore, digital literacy among the poor is low. The policy implication is to improve access for digital diffusion and provide assistance to improve digital literacy skills.
\end{abstract}

\section{Keywords:}

digital diffusion; digital literacy; digital-divide; poverty; urban poor

\section{Introduction}

Since the end of the 1990s, the studies on digital divide emerged as there have been a concerning issue regarding the gap between those who have access to digital technology such as computers and internet and those who do not have access to the technologies (van Dijk, 2006). Another study by Chinn \& Fairlie (2007) was also keen to understand the determinants of digital divide across countries in the world. Their study concluded that global digital divide is mainly determined by the income differentials across countries in the world.

The indisputable link between poverty and penetration of information and communication technology (ICT) was found by Flor (2014). There was a strong association between poverty and ICT indicators such as Internet Host per 1000 persons, telephone lines per 1000 persons, personal computer ownership and television ownership across countries in South-East Asia. The study grouped the countries into four categories regarding the poverty level and ICT indicators. Singapore and Brunei Darussalam were in the first group characterized with high standard of living (Human Development Index) and low poverty level but high ICT indicators. On the other hand, countries with high poverty levels and low standards of living such as Cambodia and Lao recorded very low ICT indicators. Indonesia and Vietnam were in the same categories and had relatively medium levels of poverty index and also relatively lower ICT indicators achievement compared to Singapore, Brunei Darussalam, Malaysia, Thailand and the Philippines.

Low-income level is considered as a main hinder factor of digital penetration. Van Dijk (2006) conducted an extensive literature on digital divide and suggested that economic 
variables have significant influence on digital inequalities. The lack of economic capacity indicates unavailability of capital and resources to access the physical technology. The same evidence is also presented by Quibria et al., (2003), OECD (2001), U.S. Department of Commerce (2002) and Chinn \& Fairlie (2007) that income differential is the main determinant of any technology diffusion such as television, radio and internet. Their studies revealed that income has a positive effect on the speed of internet diffusion across countries. The diffusion is significantly higher in the developed countries than in the developing and poor countries.

The role of income in explaining the difference of technology diffusion is related to the demand characteristics for the technology. Income is a reflection of consumers' budget constraint in purchasing the new technology. Poor people have low income that is mostly spent for basic needs such as food. The proportion of income for non-food expenditure is lower than wealthy families. Thus, poor people have low demand for the new emerging technology of the internet. Furthermore, income is related to the degree of exposure of technology to people's lives. More educated groups that are characterized with better jobs and higher income have higher demand for the technology. They have been exposed to the new technology both in daily activities and jobs-related activities than the poor.

Nevertheless, poverty is still a major issue in emerging economies such as Indonesia. The poverty level remained high, indicating that a large proportion of the population could not fulfill their basic necessities. The recent data from the Central Bureau of Statistics of Indonesia (Badan Pusat Statistik, 2020) shows that the poverty level using the Head Count Index is 9.78 percent or more than 26 million people in March 2020. More than 45 percent of the poor live in three main provinces of East Java, Central Java and West Java. In Central
Java province for example the number of poor people is close to four million people or contributed to 15 percent of total poor people in Indonesia. This number increased compared to the previous year; for example, compared to the poverty line in 2018 of 11.32 percent or approximately 3.4 million people. The poverty in urban areas contributed to almost half of the poverty rate in Central Java Province, Indonesia. More than 1.8 million poor people live in urban areas in the Central Java province. According to BPS data, two cities in the top poverty rate in the province are the district of Surakarta by 10.88 percent and the District of Magelang by 8.79 percent in 2016 or 10,630 thousand poor people.

This study is keen to understand the digital penetration in the urban neighborhood by focusing in the three urban villages with the highest number of the poor namely the urban village of Rejowinangun Selatan, Rejowinangun Utara and Wates in the District of Magelang. The digital diffusion is measured by using two indicators, namely the digital penetration and the use of technology. The digital penetration is measured to identify the affordability of the technology among the poor. The data is collected by asking ownership of the devices (hardware) to access the technology. Finally, to measure the use of the internet, we surveyed the degree of engagement of people by email and social media particularly on local government accounts.

In addition, this study aims to explore digital penetration across groups in the poor neighborhood. Following up the literature, previous studies found evidence that digital penetration is different across people with different socio-economic backgrounds, demographic characteristics and working status. Previous studies suggest that the diffusion of ICT is uneven across groups of people. In the developed countries such as the United States, the digital technology diffusion is mainly enjoyed by certain groups of people 
characterized as white skinned, men and those living in the urban areas and have high education (Goslee \& Conte, 1998; Hoffman \& Novak, 1998; Strover, 2001).

The survey of national penetration and internet users profile conducted by the World Bank (2016) shows a positive trend that the internet penetration in Indonesia is growing as more people access the internet using their smartphone. Despite a growing number of internet users, a large fraction of the population has no access to the technology. According to the World Bank publication, more than 213 million people in Indonesia are still excluded from digital diffusion. World Bank (2016) data revealed that Indonesia experiences digitaldivide because the proportion of Indonesians that have no access to technology is high. Moreover, the technology is mostly accessed by young people aged between 15 and 29 . The diffusion of the internet is also limited to regions with better telecommunication infrastructure such as in Java island and urban areas.

The paper is structured as follows. The introduction highlights the importance of the study and its contribution. It is followed by review of the literature related to urban poverty, digital diffusion and digital-divide. Furthermore, data and methodology are described in the third section followed by analysis and discussion. The paper also provides conclusion and policy recommendations generated from the findings of this study.

\section{Digital Technology, Poverty and Digital Divide}

A comprehensive literature review by Avgerou (2010) presented two perspectives about the role of ICT in development. The first perspective stands on the premise that the introduction of the ICT has significant influence in enhancing socio-economic conditions of people in developing countries as found by studies by Mann (2003); Sahay (2001); Walsham et al., (2007). ICT provides a channel to have a progressive transformation in the society either through transfer and diffusion or socially embedded innovation. The developing countries receive transfer of technology and knowledge or know how from the developed countries through the process of transfer and diffusion by using the ICT. New knowledge and technology contribute to improving efficiency and facilitating the developing countries to catching up with the developed countries. Eventually, this diffusion and transfer of technology and knowledge contribute to improvement of standard of living in the developing countries. ICT may also facilitate socially embedded innovation to improve socioeconomic conditions through locally situated action (Chrisanthi Avgerou, 2010). Under this mechanism, the transformation is conducted in the form and process that adjust with the local value and understanding. If the local society believes that the transformation enhances their socio-economic conditions, the transformation process might be more successful. Thus, the transformation process is combining the social embeddedness perspective of ICT innovation and progressive transformation through organizational change.

The second perspective of studies summarized by Avgerou (2010) perceives that the introduction of digital technology creates disruptive transformation into the society. According to this perspective, the introduction of ICT may not enhance development because the transfer and diffusion process through ICT is uneven for people across the nations (Ciborra, 2009; Wade, 2004). These findings are according to another study that despite the positive impact of digital technology to development, some studies state that different levels of digital diffusion create digital divide that further leads to digital inequality.

Previous studies for example DiMaggio \& Hargittai (2001); Goslee \& Conte (1998); Hoffman \& Novak (1998); Strover (2001) 
found that digital divide occurs as access to the internet is limited to people with a certain background, particularly those with a high income level. In addition, internet diffusion is mainly benefiting certain ethnicities, for example white-skin people in the US, male, people who live in urban areas and have a high education background. In order to identify the issue of digital divide, literature suggests to measure the level of technology penetration or diffusion and the extent of use of the technology. As discussed by DiMaggio \& Hargittai (2001), in the beginning stage of penetration, the difference is in terms of access to the technology. After the technology has been penetrated, the issue of digital divide is focused on the extent of people utilizing the internet.

As discussed in the introduction section, income level is the main determinant of access to technology according to Chinn \& Fairlie (2007); OECD (2001); Quibria et al., (2003); U.S. Department of Commerce (2002); van Dijk (2006). Low income puts pressure on the households to focus mainly on the basic needs such as food, education and health. The lack of income limits poor households to access the technology especially in the beginning of the diffusion. In the early stage of internet penetration, the cost to buy hardware infrastructure such as smartphones, personal computers and laptops was very high because the technology was expensive. Therefore, there is an inequality in technical apparatus. Kling (1996) described that the access to technology is determined by the availability of suitable equipment of computer, smartphone, software and connection. As the technology is not affordable, the poor have been excluded from the internet diffusion. Moreover, inferior technical apparatus lowers the benefits that users can generate from using the technology. For example, slower connection, old hardware and older software limit users' access to certain websites. In addition, the poor may also lower exposure to the new technology because their social interaction and working activities have less interaction with the internet. The use of technology is associated with formal jobs that require interaction with people from different locations and countries.

As technology has been diffused, the penetration has been increased because the technology is more affordable. A survey in the US found that there was an increasing penetration of the internet among low income and low educated people (Horrigan, 2000). Furthermore, a report published by the Department of Commerce (U.S. Department of Commerce, 2002) showed that there was an increased penetration of the internet among those who were excluded in the early stage of internet diffusion. As the ownership of devices that enable people to use the internet has increased, inequality may widen regarding the ability of users to utilize technology to improve their lives. As discussed by DiMaggio \& Hargittai (2001), the issue of digital divide in this stage is mostly related to people's activities in working with the internet and what people are able to do when they are online.

The digital divide in this stage is determined by the skill of users in using the technology. Referring to Kling (1996), the users should possess know-how, a mix of professional knowledge of economic resources and technical skills to exploit the benefit of internet access in enhancing professional practices. Furthermore, Wilson (2000) defined the inequality of skills as differentials in cognitive access that whether users have proper training in finding and evaluating information that they access through the internet. Specifically, Wilson (2000) identified knowledge in using the internet, which is how to $\log$ on, conduct searches and download information. This knowledge is further known as internet competence which defined as:

"the capacity to respond pragmatically and intuitively to challenges and 
opportunities in a manner that exploits the internet's potential" (Hymes, 1974).

According to Livingstone et al., (2005), digitally literate users can search efficiently by comparing a diverse range of sources of information and select the most relevant information. Digital literacy remains an issue even in developed countries such as the United Kingdom. According to a 2003 survey conducted by the British government, over half of adults chosen as a sample only have an entry level of practical skills in using ICT and the internet. Thus, most adults had low skills in terms of understanding common ICT terminology, lack of ability in basic features of software tools. Regarding specific skills in accessing the internet, Livingstone et al., (2005) found that adults' ability in using search engines for collection information was limited. Furthermore, literate users must be able to identify good sources of information by understanding the development of the technology and relating them to the forces of social, political and economic. Buckingham (2006) revealed that digital literacy includes photo-visual literacy, branching literacy, information literacy and socioemotional literacy.

Previous studies also found consistent results that older group of people generally have lower ability in adopting digital technology (Broady et al., 2010; Hale et al., 2010; Hargittai \& Hinnant, 2008; Madden, 2006; Rasi et al., 2021; Schreurs et al., 2017). Schreurs et al., (2017) mentioned that a survey and interviews with a group of older people found that older adults are not engaging with digital technology as often as younger people are. The study suggested that lack of skills of digital literacy is one of the factors that contributes to low adoption of digital technology among old people. The technology was introduced relatively recently compared to other communication technology such as telephone and television. Therefore, the older generation has not been exposed to the technology when they were young instead, they have just been introduced with the technology recently. Some studies use a concept of "second digital divide" to represent the challenge of old people in adopting digital technology. For example Chen \& Wellman (2005); Howard et al., (2010); Ono \& Zavodny (2007) argued that some groups (for example old people) are being exclude from benefiting the digital technology not because they could not afford a computer, internet connection and smartphone but because they have lack of skills to use the technology. In addition, Schreurs et al., (2017) also found that older generations need institutional and family support to be able to experience and be comfortable with the technology.

\section{Urban Poverty and Digital Divide}

Literature suggests that urban poverty should get more attention since its magnitude is increasing. Recently, more people migrated from rural to urban areas, which is known as urbanization. Mitlin (2004) suggested that more than 50 percent of the world population lives in urban areas. Furthermore, UNDP projected that more than 66 percent of the population will live in urban areas by 2050. In Indonesia, the proportion of urban population is 55 percent and it will increase to 73 percent by 2030 (United Nation Development Program, 2019). An increasing number of migrants may lead to a higher poverty level in the urban areas if the migrants have lack of skills and education. The UNDP publication shows that urbanization and city expansion will contribute to an increase of urban poverty and this number will exceed the poverty level in rural areas.

In addition to having a low income, urban poor also contend with lack of skills and can only work in the informal sector. Mitlin (2004) described that urban poor have low skills and low income. Consistent with the literature, 
a published data from the Central Bureau of Statistics in 2020 also shows that lack of education as one of main characteristics of poor people in the District of Magelang. Among the poor, more than 10 percent do not have any basic education and more than 48 percent only have basic education up to Junior High School.

The significant number of poor with little education among poor in urban areas is concerning since literature found a consistent link between poverty, lack of education and digital divide. As discussed previously, Chinn \& Fairlie (2007) study on 160 countries in the world for example found strong evidence that in addition to income inequalities, lack of education is also the main driver of digital divide. Moreover, their study showed that the largest gap between those who have access to the technology and those who have no access is relied on education differentials. Particularly, the study found that education differences measured by years of schooling contributed to 9.9 to 14.4 percent of the gaps of the rates of computer penetration.

As discussed previously, education disparity has a significant role in explaining an increase of digital divide. Education is perceived as a reliable measure of human capital. A higher level of human capital facilitates individuals to access the technology. Education enhances people's ability to learn a new technology and use it. For example, in using computers, people should have basic knowledge of literacy and of information and computer technology (ICT). In the basic education system, ICT has not been introduced to the students but has started to be introduced widely on a high education level. In addition, Chinn \& Fairlie (2007) suggested that the demand for computers is higher for educated people to support their activities for example for learning and working purposes.

Due to limited education and skills, urban poor are unable to access the formal sector and more likely to work in the informal sector. Working in the informal sector is very risky because the jobs are insecure that workers are not protected by formal contracts. Furthermore, workers in the informal sector work in long hours with poor working conditions. A study by Sinha \& Lipton (1999) argued that working in the informal sector is associated with poverty. Specifically, their study found that the poverty rate is higher among workers working in the informal sector and unprotected workers. If the poor urban workers work in the formal sector, they tend to receive low wages because they are unskilled.

Job formality may also determine access to digital technology. For those working in the informal sector, their exposure to digital technology is less because their economic activities rely on direct contact and face-toface interaction. On the other hand, workers in the formal sector must be able to use digital technology to support their daily work starting from administrative level until the managerial level. A study by Chen (2016) on three cities in developing countries namely Ahmedabad in India, Durban in South Africa and Lima in Peru showed that urban people working in the informal sector mostly utilize basic technologies to support their works. The digital technology such as mobile phone and internet is considered as advanced and the intensity of use of digital technology is varied. For blue collar workers such as waste collectors and barrow operators (non-motorized transport operators) only aware of simple mobile phones but not aware of the internet. For those who use the mobile phone, they mainly use instant messaging applications such as WhatsApp to facilitate them with customers. Furthermore, the Focus Group Discussion (FGD) conducted by Chen (2016) revealed that the use of mobile phones among the informal sector workers is for work related and organizing efforts to contact members and organize meetings with the intensity between 5 to 8 (10 scale). The use of the internet for working purposes is much less by only 1 to 5 (10 scale). 


\section{Methods}

The data was collected from the city of Magelang in the Central Java Province of Indonesia. The population includes three urban villages that have the highest poverty rateamong their surrounding areas in Magelang. The data was collected using survey techniques. The total sample is 151 respondents. As presented in the table below, the three main villages are Rejowinangun Selatan, Rejowinangun Utara and Wates. The number of poor households in these villages is higher than in other villages in the same sub district. The villages are densely populated areas characterized by a high number of populations in square meter; with a larger number of households living in a property that have no certificate and working in the informal sector.

This study measures digital diffusion and digital literacy among urban poor in three villages in the district of Magelang. The survey was conducted to cover the variation of digital diffusion and digital literacy across different genders, ages, occupations and neighborhoods. To measure the level of digital diffusion and digital literacy in the poor neighborhood, this study employs two indicators. The first indicator is digital diffusion measured by the proportion of people owned hardware or devices for accessing the internet namely mobile phone and smartphone. The second indicator is digital literacy employed to measure the extent of use of online sources of information within poor neighborhoods. Specifically, we asked the respondents on their engagement in using email and social media. Finally, we also conducted a cross-tabulation of digital diffusion and digital literacy across people with different age groups and villages to understand the potential factors that explain the difference in the level of diffusion and literacy.

\section{Results}

In terms of poverty, the data collected from the respondents show that poor people lack decent housing and health access. The data collection shows that the urban poor are eager to have more access for assistance to renovate their houses and improve their health. These responses are the top two in the list of information on assistance for people in the poor neighborhood. This data presented in table 2 shows that in addition to low income, the urban poor lack basic infrastructure (house) and services (health access). Moreover, we found that assistance for housing renovation is the highest among poor people indicating the problem in the urban poor neighborhood. The poor urban people live in small houses with many inhabitants and so the house and the village are very densely populated. This lowers the environmental support to live healthy.

Table 1.

The Number of Poor Households across Urban Village in the City of Magelang, Central Java Province

\begin{tabular}{|c|c|c|c|c|}
\hline \multirow[t]{2}{*}{ Sub District } & \multirow[t]{2}{*}{ Urban village } & \multicolumn{3}{|c|}{ Number of Poor Households } \\
\hline & & Male headed & Female headed & Total \\
\hline \multirow[t]{3}{*}{ Magelang Selatan } & Rejowinangun selatan & 545 & 165 & 710 \\
\hline & Tidar utara & 472 & 153 & 625 \\
\hline & Magersari & 430 & 119 & 549 \\
\hline \multirow[t]{3}{*}{ Magelang Tengah } & Rejowinangun utara & 775 & 151 & 926 \\
\hline & Panjang & 351 & 109 & 460 \\
\hline & Gelangan & 336 & 90 & 426 \\
\hline \multirow[t]{3}{*}{ Magelang Utara } & Wates & 308 & 88 & 396 \\
\hline & Kramat selatan & 293 & 59 & 352 \\
\hline & Potrobangsan & 288 & 77 & 365 \\
\hline
\end{tabular}

Source: The Regional Development Planning, BAPPEDA Kota Magelang 
Table 2.

Information on Assistance for People in the Poor Neighborhood

\begin{tabular}{|c|c|c|c|c|c|c|}
\hline Assistance & Trader & Housewives & Blue collar workers & Entrepreneur & Others & Total \\
\hline Housing assistance & 41.94 & 40.62 & 31.03 & 46.15 & 30.43 & 36.42 \\
\hline Health assistance & 12.9 & 25 & 24.14 & - & 8.7 & 15.23 \\
\hline Education assistance & - & 6.25 & 10.34 & 15.38 & 4.35 & 5.96 \\
\hline Loans / grants for working capital & 12.9 & - & 3.45 & 7.69 & 4.35 & 5.30 \\
\hline Skill training & 3.23 & - & 3.45 & - & 2.17 & 1.99 \\
\hline Assistance for the poor & 3.23 & - & - & - & 2.17 & 1.32 \\
\hline Others & 22.58 & 6.25 & 17.24 & 23.08 & 10.87 & 14.57 \\
\hline NA & 3.23 & 21.88 & 10.34 & 7.69 & 36.96 & 19.21 \\
\hline Total & 100 & 100 & 100 & 100 & 100 & 100 \\
\hline
\end{tabular}

Source: obtained from primary data

Table 3.

Information on Assistance for People in the Poor Neighborhood across Age Group and Gender

\begin{tabular}{|c|c|c|c|c|c|c|}
\hline & \multicolumn{3}{|c|}{ Age group } & \multicolumn{3}{|c|}{ Gender } \\
\hline & 40 y.o \& below & Above 40 y.o & Total & Female & Male & Total \\
\hline Housing assistance & 38.6 & 35.11 & 36.42 & 43.18 & 26.98 & 36.42 \\
\hline Health assistance & 17.54 & 13.83 & 15.23 & 20.45 & 7.94 & 15.23 \\
\hline Education assistance & 3.51 & 7.45 & 5.96 & 9.0 & 1.59 & 5.96 \\
\hline Loans / grants for working capital & 3.51 & 6.38 & 5.3 & 5.68 & 4.76 & 5.30 \\
\hline Skill training & 3.51 & 1.06 & 1.99 & 0 & 4.76 & 1.99 \\
\hline Assistance for the poor & 1.75 & 1.06 & 1.32 & 0 & 3.18 & 1.32 \\
\hline Others & 14.04 & 14.89 & 14.57 & 14.77 & 14.29 & 14.57 \\
\hline NA & 17.54 & 20.21 & 19.21 & 6.82 & 36.51 & 19.21 \\
\hline Total & 100 & 100 & 100 & 100 & 100 & 100 \\
\hline
\end{tabular}

Source: obtained from primary data

Poor urban areas have a lack of access for clean water and sanitation that may generate health problems such as stunting.

In addition to lack of decent housing, data in table 2 presents that urban poor neighborhoods have limited access to basic infrastructure and health. In addition, they also lack access to capital for education and business purposes. The survey data shows that the urban poor are keen to have more access to finance their children's education and skills enhancement such as training and receive loans and grants for working capital. Small businesses such as traders and entrepreneurs are asking for more information related to access for loans and grants for working assistance. Furthermore, blue collar workers and small businesses are also eager to receive more information related to training to enhance their skills. This is relevant with the literature discussion that urban poor are mostly working in the informal sector or being unskilled workers in the formal sector. Table 3 presents the lack of access to housing, basic infrastructure and capital (loans) among urban poor across age group and gender. Generally, the lack of access to housing, basic infrastructure and services and capital are similar for urban poor across age groups, younger groups with age 40 y.o and below and older groups with age 40 y.o. Meanwhile, the data comparing poverty across gender shows that the proportion of female respondents with lack of access to decent housing and health services is higher than the male group.

The tabulation presented in table 4 tries to capture the lack of access among urban poor across three villages. The data shows that the 
Table 4.

Information on Assistance for People in the Poor Neighborhood across Suburb

\begin{tabular}{lcccc}
\hline & Wates & Rejowinangun Selatan & Rejowinangun Utara & Total \\
\hline Housing assistance & 37.04 & 47.92 & 24.49 & 36.42 \\
Health assistance & 16.67 & 2.08 & 26.53 & 15.23 \\
Education assistance & 3.7 & 2.08 & 12.24 & 5.96 \\
Loans / grants for working capital & 0 & 4.17 & 12.24 & 5.30 \\
Skill training & 1.85 & 4.17 & 0 & 1.99 \\
Assistance for the poor & 1.85 & 2.08 & 0 & 1.32 \\
Others & 7.41 & 16.67 & 20.41 & 14.57 \\
NA & 31.48 & 20.83 & 4.08 & 19.21 \\
Total & 100 & 100 & 100 & 100 \\
\hline
\end{tabular}

Source: survey data

Table 5.

The Ownership of Mobile Phone

\begin{tabular}{lccccc}
\hline Proportion & Trader & Housewives & Blue collar workers & Entrepreneur & Total \\
\hline Do not owned mobile & 32.26 & 25 & 34.48 & 15.38 & 36.96 \\
Owned mobile & 67.74 & 75 & 65.52 & 84.62 & 63.04 \\
Total & 100.00 & 100.00 & 100.00 & 100.00 & 100.00 \\
\hline
\end{tabular}

observation: 104

Source: Survey data

urban poor in all three villages lack access to decent housing. The data reveals that the proportion of poor people in Rejowinangun Utara finds that they need more access to health services and education assistance.

This section presents findings of digital literacy measured by two indicators, namely digital diffusion and digital literacy. The indicator of digital diffusion is represented by the ownership of devices to take benefit of the emergence of digital technology. This study surveyed the proportion of people in poor urban neighborhoods with mobile phones. The ownership data is tabulated across working status. This study concerns four main working status observed in the data, namely traders, housewives, blue collar workers and entrepreneurs. According to the table below, the penetration of mobile phones is relatively high as more than 60 percent of people owned mobile phones. The penetration is highest for those working as entrepreneurs with 85 percent of entrepreneurs owning mobile phones. By owning the tools to take part in digital information and business, entrepreneurs have competitiveness that may further boost their business. The second group with the highest mobile phone penetration is housewives. It is consistent with the previous findings that females (housewives) have a high intention of searching for more information. This group is using mobile phones to facilitate them in searching for information. Finally, more than 30 percent of people in poor urban neighborhoods missed the opportunity to improve their life with the emergence of digital technology because they simply do not have the resource to access the medium of technology.

Mobile phones merely facilitated the text and voice communication. This device has limitations in terms of accessing digital technology using the internet. Meanwhile, there are many advancements in digital technology that require internet access. Thus, people who have access to smartphones are better off compared to those with mobile phones. This study also surveyed the penetration of smartphones among people in poor urban 
Table 6.

The Ownership of Smartphone

\begin{tabular}{lccccc}
\hline Proportion & Trader & Housewives & Blue collar workers & Entrepreneur & Total \\
\hline Do not owned smartphone & 64.52 & 50.00 & 65.52 & 46.15 & 56.52 \\
Owned smartphone & 35.48 & 50.00 & 34.48 & 53.85 & 43.48 \\
Total & 100.00 & 100.00 & 100.00 & 100.00 & 100.00 \\
\hline
\end{tabular}

observation: 104

Source: Survey data

neighborhoods. As predicted, the penetration of smartphones is lower compared to mobile phones because the price of smartphones is more expensive than the basic mobile phone. This implies that poor urban areas lack access to technology because devices are not affordable. The data shows that more than 56 percent of poor people do not own the devices and the proportions are particularly high among blue collar workers and traders. The finding is consistent with the previous data on mobile phone penetration that the penetration of digital devices is particularly lower for trader and blue-collar workers.

The measurement of digital literacy is related to the usage of poor people in digital technology specifically email and social media. The data shows that the usage level of poor people with email is very low. Furthermore, the usage of email is lower than social media. This fact shows that poor urban people are more familiar with social media as a medium of accessing the information and exchanging ideas and opinions. The usage of email is particularly low among traders and entrepreneurs. It is interesting that the business owner (micro and small business) is not aware and uses email technology to facilitate communication. Meanwhile, email is more popular among blue collar workers and housewives. Among poor people in urban areas, merely 25 percent use email, which leaves another 75 percent unaware and not using email as a medium of communication. The use of social media is higher than email where about a half of poor people in urban areas use social media.
In order to understand the low digital literacy among poor people in urban areas, this study does the cross tabulation of digital literacy across age groups and sub urbans. The data reveal that the older age group is dominated by non-users of mobile phones and smartphones. Below table shows that more than 90 percent of non-mobile phone owners are people above 40 years old. Similarly, more than 86 percent of non-smartphone owners are older people aged 40 years and above. As the older age group has lower levels of device ownership, their usage level of digital communication such as email and social media is also lower than the younger aged group. The data shows that more than 75 percent of those who do not use email and social media originated from the older group of people aged 40 and above.

Digital literacy is observed among poor people in three different sub-urban areas, namely Wates, Rejowinangun Selatan and Rejowinangun Utara. There is a clear winner in terms of digital diffusion among three poor suburban areas in the study area. The data shows that Wates has the highest penetration both for mobile phones and smartphones. Meanwhile, the ownership of digital devices such as mobile phones and smartphones is the lowest in Rejowinangun Utara. This implies that the access to digital devices is varied across villages. Furthermore, in terms of the proportion of usage of email, the highest is found in Wates and the lowest is in Rejowinangun Utara. Rejowinangun Utara also recorded the lowest users of social media. 
Table 7.

The Engagement with Email and Social Media

\begin{tabular}{llll}
\hline \multicolumn{1}{c}{ Occupation } & \multicolumn{1}{c}{ Communication media } & Not aware of them & Aware of and use them \\
\hline \multirow{2}{*}{ Trader } & Email & 18.54 & 1.99 \\
& Social Media & 7.28 & 13.25 \\
Housewives & Email & 15.89 & 5.30 \\
\multirow{3}{*}{ Blue collar workers } & Social Media & 15.23 & 5.96 \\
\multirow{2}{*}{ Entrepreneur } & Email & 13.91 & 5.30 \\
\multirow{5}{*}{ Others } & Social Media & 12.58 & 6.62 \\
& Email & 5.96 & 2.65 \\
\multirow{3}{*}{ Total } & Social Media & 3.31 & 5.30 \\
& Email & 20.53 & 9.93 \\
\hline
\end{tabular}

Source: Survey data

Table 8.

Demography Profile and Digital Diffusion and Digital Literacy

\begin{tabular}{|c|c|c|c|c|c|c|c|c|}
\hline \multirow{2}{*}{$\begin{array}{c}\text { Age group/ } \\
\text { Digital Literacy }\end{array}$} & \multicolumn{2}{|c|}{$\begin{array}{c}\text { Mobile } \\
\text { ownership }\end{array}$} & \multicolumn{2}{|c|}{$\begin{array}{l}\text { Smartphone } \\
\text { ownership }\end{array}$} & \multicolumn{2}{|c|}{ Email } & \multicolumn{2}{|c|}{ Social Media } \\
\hline & $\begin{array}{l}\text { No } \\
(\%)\end{array}$ & $\begin{array}{l}\text { Yes } \\
\text { (\%) }\end{array}$ & $\begin{array}{l}\text { No } \\
(\%)\end{array}$ & Yes $(\%)$ & No $(\%)$ & $\begin{array}{l}\text { Yes } \\
(\%)\end{array}$ & $\begin{array}{l}\text { No } \\
(\%)\end{array}$ & $\begin{array}{l}\text { Yes } \\
(\%)\end{array}$ \\
\hline 40 y.o and below & 8.51 & 50.96 & 13.79 & 70.31 & 23.01 & 81.58 & 22.08 & 54.05 \\
\hline above 40 y.o & 91.49 & 49.04 & 86.21 & 29.69 & 76.99 & 18.42 & 77.92 & 45.95 \\
\hline Total & 100 & 100 & 100 & 100 & 100 & 100 & 100 & 100 \\
\hline
\end{tabular}

Source: obtained from primary data

Table 9.

Demography Profile and Digital Diffusion and Digital Literacy

\begin{tabular}{|c|c|c|c|c|c|c|c|c|}
\hline \multirow{2}{*}{$\begin{array}{l}\text { Urban Village/ } \\
\text { Digital Literacy }\end{array}$} & \multicolumn{2}{|c|}{$\begin{array}{c}\text { Mobile } \\
\text { ownership }\end{array}$} & \multicolumn{2}{|c|}{$\begin{array}{c}\text { Smartphone } \\
\text { ownership }\end{array}$} & \multicolumn{2}{|c|}{ Email } & \multicolumn{2}{|c|}{ Social Media } \\
\hline & $\begin{array}{l}\text { No } \\
(\%)\end{array}$ & $\begin{array}{l}\text { Yes } \\
(\%)\end{array}$ & $\begin{array}{l}\text { No } \\
(\%)\end{array}$ & $\begin{array}{l}\text { Yes } \\
\text { (\%) }\end{array}$ & $\begin{array}{l}\text { No } \\
(\%)\end{array}$ & $\begin{array}{l}\text { Yes } \\
(\%)\end{array}$ & $\begin{array}{l}\text { No } \\
(\%)\end{array}$ & $\begin{array}{l}\text { Yes } \\
(\%)\end{array}$ \\
\hline Wates & 21.28 & 42.31 & 27.59 & 46.88 & 29.2 & 55.26 & 40.26 & 31.08 \\
\hline Rejowinangun Selatan & 27.66 & 33.65 & 32.18 & 31.25 & 33.63 & 26.32 & 6.49 & 58.11 \\
\hline Rejowinangun Utara & 51.06 & 24.04 & 40.23 & 21.88 & 37.17 & 18.42 & 53.25 & 10.81 \\
\hline Total & 100 & 100 & 100 & 100 & 100 & 100 & 100 & 100 \\
\hline
\end{tabular}

Source: obtained from primary data

\section{Discussion}

The survey data reveals important findings about urban poverty characteristics and the diffusion of digital technology and digital literacy among urban poor neighborhoods in the city of Magelang in the Central Java Province. As discussed in the introduction, poverty remains an important issue in Indonesia and the Central Java Province contributes to 15 percent of poor people. The literature predicts that the proportion of people living in urban areas increases and will reach 73 percent in 2030.

This study found that urban poor living standard is shown by low income, lack of decent housing, living in densely populated areas, lack of basic infrastructure of sanitation and health services, working in an informal sector, lack of skills, unskilled workers and lack of access to capital and education assistance. 
The three areas of study are the villages of Rejowinangun Selatan, Rejowinangun Utara and Wates that have the highest proportion of poor households in the subdistrict. Among the three villages, the proportion of the poor is the highest in Rejowinangun Utara that contributes to more than 51 percent of poor households in the sub district of Magelang Tengah. In two other villages, Rejowinangun Selatan and Wates, the contribution of poor households within the sub district are about 35-37 percent.

This study also found that urban poor are working in the informal sector for example by being traders (street vendors) and having micro and small business. Urban poor also have a lack of skills and education because they do not have sufficient income to pursue education and non-formal training. Lack of skills is one of the constraints for the poor to have decent work since most of the workers are blue collar workers. The participation of women in the labor force is relatively low as the data of working status shows that the proportion of housewife in the survey data is significant.

This study finds evidence that poverty may lower the diffusion of digital technology. The descriptive data shows that more than 35 percent of urban poor have no access to mobile phones. The diffusion of smartphones is even less that more than 65 percent of the poor have no access to the device. In terms of digital technology diffusion among the urban poor, those who own small businesses have the largest diffusion level as the technology enables them to contact their customers and organize some works. In addition, the female group of housewives has a relatively higher digital diffusion level of more than a half of respondents have smartphones. This is interesting since previous studies found that the digital technology diffusion is higher among males group compared to females' group. Additional information collected from direct observation and Focus Group Discussion found that the female group has a significant role in the poor urban neighborhood to distribute information across the villages both by using traditional means of face to face interaction and digital technology using short text message and WhatsApp application.

In terms of digital literacy, this study finds supporting evidence to the literature (Kling, 1996; Wilson, 2000) that the poor have low digital literacy due to lack of technical skill and experience. The lack of skills is prevalent among the poor because the majority have only a low education, so they do not have sufficient cognitive skills to be able to exploit the benefit of the internet. The survey data shows that only 25 percent of respondents are aware of email and 49 percent are aware of social media. These findings show that the digital literacy of urban poor is relatively low and they just use the basic properties of the internet and are not being able to utilize more advanced properties such as log on, conduct searches and download information.

Cross tabulation data also shows that both digital diffusion and digital literacy are lower in the village with the highest proportion of poor people. The digital diffusion in terms of mobile phones is only 24 percent in the village of Rejowinangun Utara, the village with the highest proportion of poor households. Furthermore, about 80 percent of respondents in the Rejowinangun Utara have no access to smartphones and the literacy of digital technology is very low with only 18 percent aware of emails and only 11 percent aware of social media.

Access to digital technology is also higher among younger groups of urban poor. This finding is consistent with previous literature that show that the older population does not adopt digital technology as much as young group do (Broady et al., 2010; Hale et al., 2010; Hargittai \& Hinnant, 2008; Madden, 2006; Rasi et al., 2021; Schreurs et al., 2017). This study found that both the digital diffusion and digital literacy between the young and old groups is significantly different. The diffusion of smartphone technology among the younger 
group is more than 70 percent but it is only 30 percent among the older group. Furthermore, the digital literacy measured by the awareness of email is much larger to the younger group by more than 80 percent while it is only less than 20 percent among the older group. These findings show even among the urban poor neighborhood, the digital divide persists between the young groups and the old group. This implies that the older group are being excluded to benefit from the digital technology (W. Chen \& Wellman, 2005; Howard et al., 2010; Ono \& Zavodny, 2007).

\section{Conclusion}

This study found that there is a digital divide problem within people in urban areas particularly for people with low income. The digital diffusion is still low particularly for smartphones. The main factor is the income level of the poor is low so they could not afford to buy the devices. Moreover, the diffusion is dominated by certain groups, for example younger people and females. Furthermore, digital literacy is low because poor people have low engagement with digital information. The number of email users is very low and the number of users of social media is also still relatively lower.

The policy implications for the local government are as follows. Urban poor are keen to have more information particularly on assistance programs from the government. However, since the digital diffusion is still low, the urban poor as the targeted segment of the poverty eradication program still could not enjoy the benefit of improved access for services through digital platforms. Therefore, the information should be delivered using two platforms of traditional channel from the head of neighborhood and digital platform using website, social media and applications. As digital diffusion increases, local governments should provide assistance for urban poor to improve their digital literacy so that they can enhance their ability to access and select relevant and valid information using digital platforms.

\section{References}

Avgerou, Chrisanthi. (2010). Discourses on ICT and development. Information Technologies and International Development, 6, 1-18.

Badan PusatStatistik. (2020). Persentase penduduk miskin menurut provinsi. Persentase Penduduk Miskin Menurut Provinsi.

Broady, T., Chan, A., \& Caputi, P. (2010). Comparison of older and younger adults' attitudes towards and abilities with computers: Implications for training and learning. British Journal of Educational Technology, 41(3), 473-485. https://doi. org/10.1111/j.1467-8535.2008.00914.x

Buckingham, D. (2006). Defining digital literacy What do young people need to know about digital media? Digital Kompetanse, 1(4), 263-276.

Chen M.A. (2016). Technology, informal workers and cities: insights from Ahmedabad (India), Durban (South Africa) and Lima (Peru). Environment and Urbanization, 28(2), 405-422. https://doi. org/10.1177/0956247816655986

Chen, W., \& Wellman, B. (2005). Minding the cyber-gap: The Internet and social inequality. In M. Romero \& E. Margolis (Eds.), The Blackwell companion to social inequalities (pp. 523-545). Blackwell.

Chinn, M. D., \& Fairlie, R. W. (2007). The determinants of the global digital divide: A cross-country analysis of computer and internet penetration. Oxford Economic Papers, 59(1), 16-44. https://doi. org/10.1093/oep/gpl024

Ciborra, C. U. (2009). Interpreting E-government and Development: Efficiency, Transparency or Governance at a Distance? In Bricolage, Care and Information. Palgrave Macmillan UK. https://doi.org/10.1057/9780230250611_5 
DiMaggio, P., \& Hargittai, E. (2001). From the 'Digital Divide' to 'Digital Inequality': Studying Internet Use as Penetration Increase.

Flor, A. G. (2014). ICT and Poverty: The Indisputable Link. https://www.researchgate.net/ publication/246409174

Goslee, S., \& Conte, C. (1998). Losing ground bit by bit: Low-income communities in the information age.

Hale, T. M., Cotten, S. R., Drentea, P., \& Goldner, M. (2010). Rural-Urban Differences in General and HealthRelated Internet Use. American Behavioral Scientist, 53(9), 1304-1325. https://doi. org/10.1177/0002764210361685

Hargittai, E., \& Hinnant, A. (2008). Digital Inequality. Communication Research, 35(5), 602-621. https://doi. org/10.1177/0093650208321782

Hoffman, D. L. , \& Novak, T. P. (1998). The Evolution of the Digital Divide: Examining the Relationship of Race to Internet Access and Usage Over Time.

Horrigan, J. (2000). New internet users: What they do on-line, what they don't, and Implications for the 'Net's' Future.

Howard, P. N., Busch, L., \& Sheets, P. (2010). Comparing Digital Divides: Internet Access and Social Inequality in Canada and the United States. Canadian Journal of Communication, 35(1), 109-128. https://doi. org/10.22230/cjc.2010v35n1a2192

Hymes, D. (1974). Foundations in socioliguistics; An ethnographic approach. University of Pennsylvania Press.

Kling, R. (1996). Computerization and Controversy: Value Conflicts and Social Choices. Academic Press.

Livingstone, S., Bober, M., \& Helsper, E. (2005). Internet literacy among children and young people.

Madden, M. (2006). Internet penetration and impact. Pew Internet and American Life Project.
Mann, C. L. (2003). Information Technologies and International Development: Conceptual Clarity in the Search for Commonality and Diversity. International Technologies $\mathcal{E}$ International Development, 1(2), 67-79.

Mitlin, D. (2004). Understanding Urban Poverty What the Poverty Reduction Strategy Papers tell $u$.

OECD. (2001). Understanding the digital divide.

Ono, H., \& Zavodny, M. (2007). Digital inequality: A five country comparison using microdata. Social Science Research, 36(3), 1135-1155. https://doi.org/10.1016/j. ssresearch.2006.09.001

Quibria, M. G., Ahmed, S. N., Tschang, T., \& Reyes-Macasaquit, M.-L. (2003). Digital divide: determinants and policies with special reference to Asia. Journal of Asian Economics, 13(6), 811-825. https://doi. org/10.1016/S1049-0078(02)00186-0

Rasi, P., Vuojärvi, H., \& Rivinen, S. (2021). Promoting Media Literacy Among Older People: A Systematic Review. Adult Education Quarterly, 71(1), 37-54. https:// doi.org/10.1177/0741713620923755

Sahay, S. (2001). Introduction to the special issue on "IT and Health Care in Developing Countries. Electronic Journal on Information Systems in Developing Countries, 5(0), 1-6. Schreurs, K., Quan-Haase, A., \& Martin, K. (2017). Problematizing the Digital Literacy Paradox in the Context of Older Adults' ICT Use: Aging, Media Discourse, and Self-Determination. Canadian Journal of Communication, 42(2), 359-377. https:// doi.org/10.22230/cjc.2017v42n2a3130

Sinha, S., \& Lipton, M. (1999). Damaging fluctuations, risk and poverty: A Review.

Strover, S. (2001). Rural internet connectivity. Telecommunications Policy, 25(5), 331347. https://doi.org/10.1016/S03085961(01)00008-8

United Nation Development Program. (2019). UNDP Indonesia Sustainable Urban Development Strategy. 
Tri Mulyaningsih, Rutiana Wahyunengseh, Sri Hastjarjo: Poverty and Digital Divide: A Study in Urban Poor Neighborhoods

U.S. Department of Commerce. (2002). A Nation online: How Americans are expanding their use of the internet.

van Dijk, J. A. G. M. (2006). Digital divide research, achievements and shortcomings. Poetics, 34(4-5), 221-235. https://doi. org/10.1016/j.poetic.2006.05.004

Wade, R. (2004). Bridging the digital divide: new route to development or new form of dependency? In C Avgerou, C. Ciborra, \& F. Land (Eds.), The Social Study of
Information and Communication Technology: Innovation, Actions, and Contexts (pp. 185-206). Oxford University Press.

Walsham, G., Robey, D., \& Sahay, S. (2007). Foreword: Special issue on information systems in developing countries. MIS Quarterly, 317-326.

Wilson, E. (2000). Closing the digital divide: An initial review. Briefing the President.

World Bank. (2016). World Development Report 2016: Digital Dividends. 